\title{
Holocene paleoclimate data from the Arctic: testing models of global climate change
}

\author{
CAPE Project Members ${ }^{1,2}$ \\ University of Boulder at Colorado, Institute of Arctic \& Alpine Research, 1560 30th Street, Campus Box 450, Boulder, CO 80309-0450, USA
}

\begin{abstract}
To evaluate the spatial variability of Arctic climate change during the present interglacial, CAPE Project Members compiled well-dated terrestrial, marine, and ice-core paleoenvironmental records spanning the past 10-12 thousand years (ka). Six tundra biomes of increasing summer temperature requirements were defined based on regionally coherent pollen assemblages. Using a rule-based approach, pollen spectra were converted to tundra, forest/tundra, or forest biomes ranked by their average growing season requirements. Marine sea-surface reconstructions were based on proxy data following a similar rule-based approach. From these data-based reconstructions, departures in summer temperatures from modern normals were calculated in 1 ka time slices through the Holocene. To test predictive models, data-based summer temperature reconstructions were compared with general circulation model (GCM) simulations for $10 \mathrm{ka}$ and $6 \mathrm{ka}$ ago. Paleodata and model results both show that warming occurred earlier across Beringia and Asia relative to lands adjacent to the North Atlantic, and that Late Holocene cooling was most apparent in the North Atlantic region. However, the GCM over-predicts the magnitude of Mid-Holocene warming over northern Asia and underestimates the intensification of the North Atlantic drift in the early Holocene. Strong spatial variability in environmental response during the Holocene, despite symmetric (insolation) forcing, suggests that any future changes, whether caused by anthropogenic or natural factors, are unlikely to result in a uniform change across the Arctic, adding additional complexity to forecasts of global impacts. (C) 2001 Elsevier Science Ltd. All rights reserved.
\end{abstract}

\section{Introduction}

The record of environmental change preserved in sedimentary archives provides one of the few independent means of validating predictive climate models (Webb et al., 1987; Bartlein et al., 1998; Jolly et al., 1998; Joussaume and Taylor, 1998; Webb, 1998; Kohfeld and Harrison, 2000). Although the Arctic covers only a modest fraction of the planet, it includes many of the most sensitive elements of the planetary system likely to change in the next several decades to centuries (Overpeck

\footnotetext{
${ }^{1}$ Corresponding author. G. Miller. Tel.: + 1-303-492-6387; fax: + 1303-492-6388; e-mail address: gmiller@colorado.edu

${ }^{2}$ CAPE, Circum-Arctic PaleoEnvironments, is a component of the International Geosphere-Biosphere Program's Past Global Changes (PAGES) Project. The syntheses reported here were initially compiled at a CAPE workshop held in Lammi, Finland in April 1997, and subsequently enhanced in several informal smaller working group meetings in Europe and North America. List of CAPE Steering Committee is given in Appendix A and attendees at the CAPE Holocene Meeting in Appendix B.
}

et al., 1997), and greenhouse warming is predicted to be greater in the polar regions than elsewhere. According to recent numerical simulations of future climate under $2 \times \mathrm{CO}_{2}$ scenarios, the Arctic is predicted to warm by up to $8^{\circ} \mathrm{C}$ (Mitchell et al., 1995). Changes in albedo, associated with variations in the distribution and duration of seasonal snowcover or the extent of boreal forests (Bonan et al., 1995; TEMPO, 1996), and changes in ocean-atmosphere heat transfer linked to shifts in sea-ice cover, are dominantly Arctic phenomena with global influence. Furthermore, changes in sea ice, runoff from Arctic rivers, or ice-sheet discharge will alter the salinity of the polar oceans and may impact oceanic thermohaline circulation (Stein, 1998), the largest non-linearity in the climate system. North of $60^{\circ} \mathrm{N}$, the oceans are responsible for one-third of the total heat energy transported by the combined ocean-atmosphere system (Carissmo et al., 1985); virtually all of this oceanic transport is via the North Atlantic drift (NAD); Hastenrath, 1982). Changes in the intensity of the NAD, and any changes in the associated thermohaline circulation, will impact strongly the energy balance of the adjacent regions, most noticeably Scandinavia and NW Europe. 
Regional reconstructions of paleoenvironmental change in the Arctic are currently the focus of several national and international research programs. However, to fully evaluate the role of the Arctic in the global climate system necessitates a circum-Arctic approach. To achieve a hemispheric synthesis, CAPE Project Members compiled well-dated sites that characterize the Earth's surface throughout the Arctic at $1 \mathrm{ka}$ time slices for the Holocene (Hicks, 1997). The primary proxies were pollen assemblages, planktonic marine organisms (foraminifera, diatoms, coccoliths, and dinoflagellate cysts), and $\delta^{18} \mathrm{O}$ from ice cores. For the Holocene, most boundary conditions varied only slightly from the present and a wide range of terrestrial and marine climate proxies exist as continuous, well-dated time-series.

The Holocene includes the interval of instrumental and written records, allowing a firmly based calibration of proxy data to specific climate variables. Consequently, it is ideally suited for detailed global compilations and for comparisons between data-based and model-simulated reconstructions of environmental change. We focused primarily on changes in summer temperatures, because the proxy evidence in the Arctic is most sensitive to this climate parameter. The 6 and $10 \mathrm{ka}$ time slices were identified following established guidelines (Oldfield, 1998); calendrical ages are used throughout the text: 6000 calendar years is approximately the same as 6000 radiocarbon years, whereas 10,000 calendar years corresponds to approximately 9000 radiocarbon years.

\section{Proxy records}

\subsection{Terrestrial summer temperature reconstructions}

On land, summer temperature reconstructions are based primarily on palynological data preserved in sedimentary archives, supplemented by other terrestrial proxy summer temperature data where available. Since the early vegetation synthesis of COHMAP (1988), advances have been made in the conversion of site-specific changes in pollen assemblages to changes in actual vegetation assemblages. Much of this effort has focused on utilizing objective, rule-based classification systems, a process generally referred to as biomization. Through the biomization process, plant taxa represented in the pollen spectra are converted to a limited number of plant functional types (Prentice et al., 1996). Biomes are then defined by combinations of plant functional types, providing a basis for data-model comparisons.

In recent years, several models have been developed that offer improved simulation of vegetation from GCM output (e.g. Bergengren and Thompson, in review; Foley et al., 1996; Prentice et al., 1992). The potential feedback of vegetation on regional climate has been quantified, and several regional studies illustrate the importance of correctly incorporating vegetation in any past or future global climate simulation (e.g., Foley et al., 1994; Kutzbach et al., 1996; TEMPO, 1996). Biomes reconstructed from GCM simulations for several time slices have been compared with vegetation assemblages reconstructed from proxy data for a number of specific time slices over the past $21 \mathrm{ka}$ (see, for example, Webb, 1998).

Despite significant advances in regional to global syntheses of vegetation change through time, past changes in Arctic vegetation have been consistently over-simplified, obscuring significant changes in tundra vegetation that carry paleoclimatic information. Most global vegetation classification schemes have only one, or at most two classifications of surface conditions north of the treeline: tundra and polar desert (e.g., Prentice and Webb III, 1998; Williams et al., 1998). In more recent biome classifications, tundra vegetation may be divided into two classifications: areas dominated by upright shrubs vs. those dominated by prostrate plants. While these simple classifications may capture the dominant biosphere-atmosphere feedbacks, they reduce the information contained in more subtle changes in tundra vegetation that reflect systematic changes in growing season temperatures and moisture availability.

\subsection{Tundra biomes}

Synthesizing site-specific vegetation reconstructions into regional patterns of vegetation change for the circum-Arctic requires common guidelines (Prentice and Webb III, 1998). One of the goals of the CAPE Lammi meeting was to bring together palynologists working across the circum-Arctic to achieve a common basis for the reconstruction of changes in tundra vegetation, and to develop a more sensitive and broadly applicable classification of tundra ecosystems. We developed a consensus subdivision of tundra vegetation based on pollen preserved in sedimentary archives, the CAPE Tundra Biomes Scheme (Fig. 1). This classification scheme consists of six tundra biomes (1-6, Fig. 1), and one forest/tundra biome. The biomes are ranked so that they reflect generally increasing warmth and duration of the growing season. Within the Fellfield and Gramanoid Tundra Biomes, a further two-part subdivision is possible, reflecting consistent differences in mean growing season temperatures, whereas two distinct shrub tundra biomes have overlapping growing season temperature constraints. This results in seven distinct and widely applicable growing season categories for the tundra, interpreted in terms of increasing summer (JJA) temperatures (A-G, Fig. 1).

To synthesize available well-dated pollen records from the circum-Arctic, CAPE convened 12 regional working groups (Fig. 2) that brought together experts working in each region to identify and compile well-dated Holocene records prior to the Lammi meeting. Conversion of 


\begin{tabular}{|c|c|c|c|c|c|c|}
\hline \multicolumn{7}{|c|}{ CAPE Tundra Biomes } \\
\hline \multicolumn{2}{|c|}{$\begin{array}{l}\text { Vegetation } \\
\text { group }\end{array}$} & \multicolumn{3}{|c|}{ Vegetation type } & \multicolumn{2}{|c|}{$\begin{array}{l}\text { lative change } \\
\text { ummer temp. }\end{array}$} \\
\hline \multirow{8}{*}{ 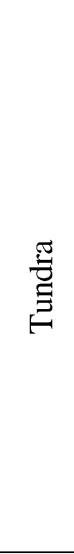 } & \multirow{2}{*}{1} & \multirow{2}{*}{$\begin{array}{l}\text { Sparse } \\
\text { vegetation/ } \\
\text { Fellfield }\end{array}$} & $1 \mathrm{a}$ & Woody species absent & A & \\
\hline & & & $1 b$ & Woody species present & $\mathrm{B}$ & 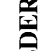 \\
\hline & \multirow[b]{2}{*}{2} & \multirow[b]{2}{*}{$\begin{array}{c}\text { Graminoid } \\
\text { Tundra }\end{array}$} & $2 a$ & Poaceae dominant & $\mathrm{C}$ & \\
\hline & & & $2 b$ & $\begin{array}{c}\text { Poaceae and Cyperaceae } \\
\text { or } \\
\text { Poaceae }+ \text { Artemisia } \\
+ \text { other herbs }\end{array}$ & $\mathrm{D}$ & \\
\hline & 3 & \multicolumn{3}{|c|}{ Heath Tundra } & $\mathrm{E}$ & \\
\hline & 4 & \multicolumn{3}{|c|}{ Shrub-Graminoid Tundra } & $\mathrm{F}$ & \\
\hline & 5 & $\begin{array}{l}\text { Deciduous } \\
\text { Shrub } \\
\text { Tundra } \\
\end{array}$ & & $\begin{array}{c}\text { Betula dominated } \\
\text { or } \\
\text { Inus }+ \text { Betula dominated }\end{array}$ & \multirow[t]{2}{*}{ G } & \\
\hline & 6 & \multicolumn{3}{|c|}{ Pinus pumila dominated shrub tundra } & & \\
\hline 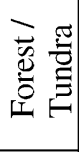 & 7 & & $\begin{array}{r}\mathrm{ra}+\mathrm{e} \\
\text { Tund } \\
\text { Tund } \\
\text { Popul }\end{array}$ & $\begin{array}{l}\text { vergreen (any type) } \\
\text { ra + Larix } \\
\text { ra + Betula } \\
\text { us woodland }\end{array}$ & $\mathrm{H}$ & \\
\hline \multirow[t]{2}{*}{ 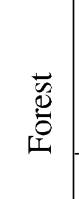 } & 8 & \multicolumn{3}{|c|}{$\begin{array}{c}\text { Betula dominant } \\
\text { Larix dominant } \\
\text { Picea dominant } \pm \text { boreal hardwoods } \\
\text { Pinus dominant } \pm \text { boreal hardwoods }\end{array}$} & I & 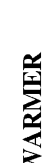 \\
\hline & 9 & \multicolumn{3}{|c|}{ Boreal conifers + temporate hardwoods } & $\mathrm{K}$ & \\
\hline
\end{tabular}

Fig. 1. CAPE tundra biome classification scheme.

pollen data to tundra biomes follows a rule-based strategy developed by each of the working groups (e.g. Tables $1 \mathrm{a}$ and $1 \mathrm{~b}$ ). For each sector, the relevant tundra biomes were assigned characteristic pollen assemblages. Because of regional variations in vegetation assemblages, pollen definitions of a specific tundra biome may vary in the details of their pollen composition between the 12 regions. Fossil pollen assemblages were classified into their appropriate biome using these characteristics, coupled with the expert local knowledge within each regional working group. Based on the changes in biomes through time, relative summer temperature anomalies were computed for each site.

Terrestrial summer temperature reconstructions are derived from 168 sites at $10 \mathrm{ka}$ and 208 sites at $6 \mathrm{ka}$ (Fig. 3); all sites are north of $59^{\circ} \mathrm{N}$. Estimates of summer temperature change are based on the scaled difference (cold-warm scale of letters A-K in Fig. 1) between the fossil biome reconstructed from the pollen data and the reconstructed modern biome at the same site, although this is not a strictly linear expression of summer temperature. The basic pollen counts for the sites used in this compilation are archived in the North American pollen database (NAPD), European pollen database (EPD), or in the Paleoclimate from Arctic lakes and estuaries (PALE) pollen databases.

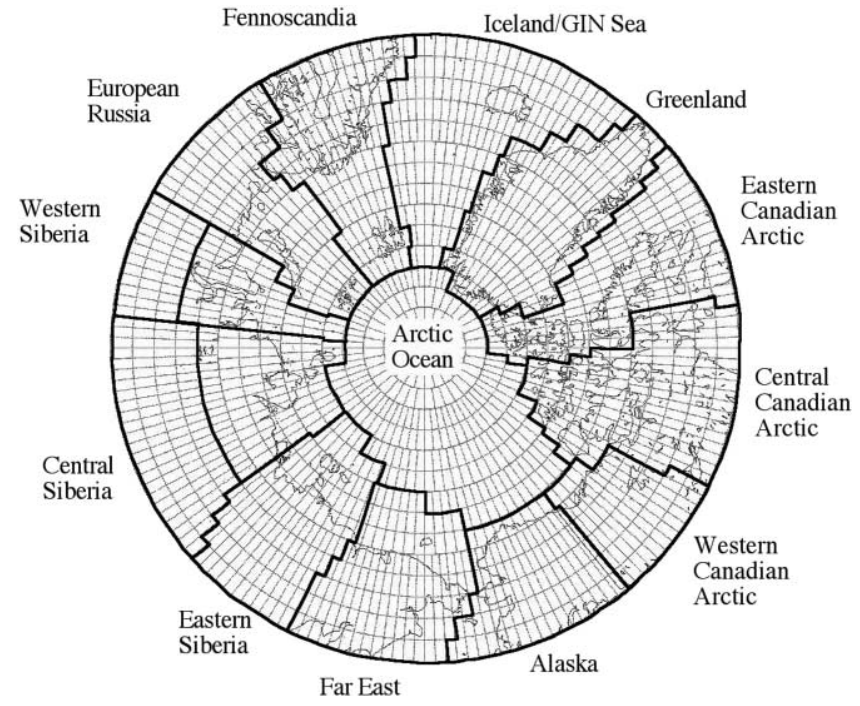

Fig. 2. Polar projection showing the 13 regions that were considered at the CAPE Lammi meeting. For each region, a regional coordinator was charged with compiling the Holocene sites that met the established protocols for use in the synthesis effort.

\subsection{Marine SST reconstructions}

Biotic proxies preserved in marine sediment cores provide the basis for past SST reconstructions. Chronological uncertainties and difficult access to optimal core localities limit the density and spatial distribution of marine paleodata; 23 cores meet our criteria for secure geochronologies and reliable paleoenvironmental proxies. Most of these cores come from regions influenced by Atlantic water. Key oceanographic characteristics are the distribution of seasonal and permanent sea ice, sea-surface temperatures (SST) and salinity. SSTs were estimated from transfer functions constructed from diatom (Koç et al., 1993), dinoflagellate (de Vernal et al., 1994; 1997), and planktonic foraminiferal assemblages (Pflaumann et al., 1996; Waelbroeck et al., 1998). Where only benthic foraminiferal data were available, SSTs were inferred from species distributions and their links to hydrographic conditions known today (Feyling-Hanssen et al., 1971; Sejrup et al., 1981, Mudie et al., 1984; Jennings and Weiner, 1996). We developed a classification system based on these parameters (Table 2) that can be objectively applied.

\subsection{Ice cores}

Estimates of Holocene summer temperatures at or near the summits of ice caps in Greenland, NE Canada, and Russia are derived from oxygen isotope ratios in ice and reconstructed intensity of summer melt (Koerner, 1977), with secure time control within the Holocene provided by layer counting. 
Table 1

Examples of a rule-based conversion of pollen-data to vegetation type for Fennoscandinavia, Svalbard, Karelia and the Kola Peninsula (Table 1a) and for the Eastern Canadian Arctic and Greenland (Table 1b); each regional group derived a similar table, with subtle variations reflecting vegetation differences throughout the Arctic

(a) Fennoscandia, Svalbard, Karelia and the Kola Peninsula vegetation type definitions in terms of specific pollen parameters (all percentages are of the total pollen sum excluding spores). Only those vegetation types which occur in this section of the Arctic are defined

Tundra

1. Sparse vegetation/Fellfield

$1 \mathrm{~b}$ Woody species present

Cyperaceae 5-10\%, Saxifraga 5-10\%, Rumex/Oxyria 2-5\%,

Salix present. Pollen concentration values very low.

2. Graminoid Tundra

2a Poaceae dominant

Poaceae $70-80 \%$

2b Poaceae and Cyperaceae

Poaceae $>20 \%$, Cyperaceae $60-70 \%$

3. Heath Tundra

Ericales $>5 \%$, Betula (mostly B.nana type) $>10 \%$, NAP $>30 \%$, Salix present

Total pollen influx $<1000$ grains $\mathrm{cm}^{-2}$ year $^{-1}$

4. Shrub-Graminoid Tundra

Betula 20\% Poaceae 40-60\%

5. Deciduous Shrub Tundra

Betula dominated

Betula $20-30 \%$, NAP $>30 \%$

Forest/Tundra

7. Tundra + Betula

Betula $>30 \%<60 \%$, Pinus $<40 \%$ (Pinus influx $<500$ grains $^{-2}$ year $^{-1}$ ), NAP $15 \%$

Forest

8. Betula dominant

Betula $>60 \%$, Pinus $<20 \%$

or

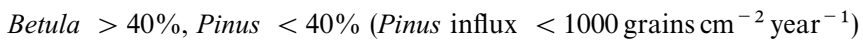

Picea dominant + boreal hardwoods

Picea $>10 \%$

Pinus dominant + boreal hardwoods

Pinus $>40 \%$, NAP $<5 \%$, Ericales $<1 \%$, Alnus present

9. Boreal conifers + temperate hardwoods

At least 2 species from Quercetum mixtum forest together $>5 \%$

(b) Eastern Canadian Arctic, Greenland vegetation type definitions in terms of specific pollen parameters (all percentages are of the total pollen sum excluding spores). Only those vegetation types which occur in this section of the Arctic are defined

Tundra

1. Sparse vegetation/Fellfield

1a Woody species absent

Very low pollen concentrations. Typical elements include. Oxyria, Saxifraga, Polypodiaceae, Bassicacea and Poaceae

$1 \mathrm{~b}$ Woody species present

Very low pollen concentrations. Typical elements include: Oxyria,

Saxifraga, Polypodiaceae, Bassicacea, Poaceae, Ericales, Salix, Dryas

2. Graminoid Tundra

2a Poaceae dominant

Poaceae $>30 \%$ (commonly $>50 \%$ ), grass at least twice as abundant as

sedge, Oxyria common. Filicales common.

2b Poaceae and Cyperaceae

$<20 \%$ Poaceae, more sedge than grass, variable Salix, Ericaceae, possible Oxyria.

3. Heath Tundra

Salix, Betula, Ericaceae, Cyperaceae, Bassicacea

4. Shrub-Graminoid Tundra

Salix, Betula and Alnus. Also Poaceae, Cyperaceae, locally Juniperus

5. Deciduous Shrub Tundra

5a Betula dominated

Betula pubescence, Juniperus

$5 \mathrm{~b}$ Alnus dominated

Alnus dominant; common Picea, some Pinus

Forest

8. Betula dominant

$>80 \%$ Betula pubescence, also Salix, Poaceae. 


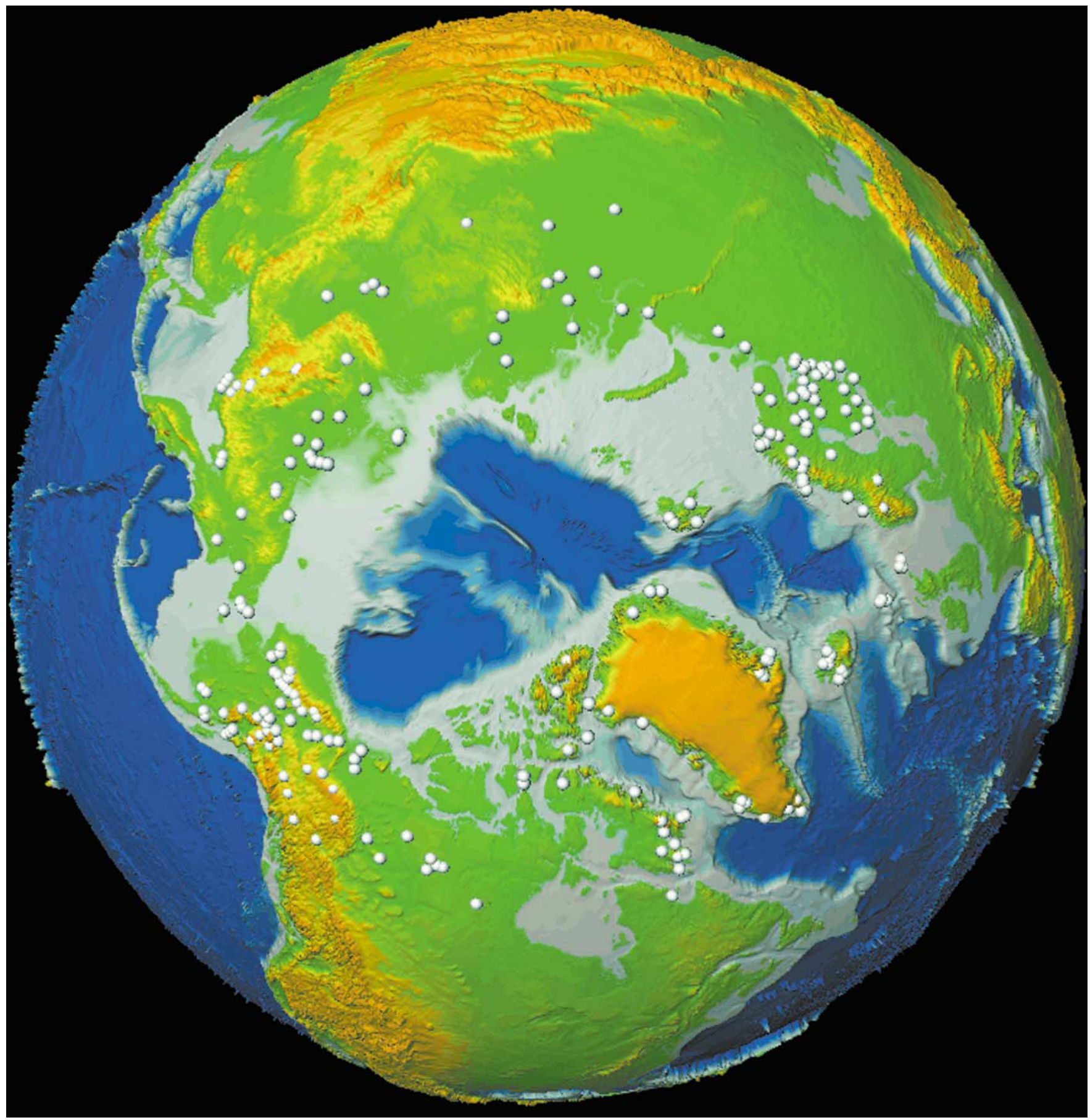

Fig. 3. Map of all pollen sites in the Arctic (6 ka).

\section{Paleoclimate models}

We used the NCAR GENESIS v.2 (Thompson and Pollard, 1997) general circulation model (GCM) to simulate conditions at $10 \mathrm{ka}, 6 \mathrm{ka}$ and present (Pollard et al., 2000), and to compare with our data-based paleoenvironmental reconstructions. GENESIS v. 2 utilizes an atmospheric general circulation model with a spectral re- solution of T31 $\left(\mathrm{ca} .3 .75^{\circ} \times 3.75^{\circ}\right)$ coupled with multi-layer models of surface phenomena (vegetation, soil, glacier ice, snow) at a resolution of $2^{\circ} \times 2^{\circ}$. The ocean is represented by a $50 \mathrm{~m}$-thick mixed-layer slab ocean, with the oceanic heat flux prescribed at modern values. Because thermohaline circulation is not thought to have undergone major reorganization within the Holocene, no changes related to deep-ocean circulation are incorporated 
Table 2

Rule-based derivation of marine SST from biotic proxy evidence

\begin{tabular}{|c|c|c|c|c|c|c|c|c|c|c|}
\hline $\begin{array}{l}\text { Nordic Seas } \\
\text { Zones }\end{array}$ & SST & SSS & $\begin{array}{l}\text { Candian water } \\
\text { zones }\end{array}$ & SST & SSS & $\begin{array}{l}\text { Sea ice } \\
\text { (All areas) }\end{array}$ & $\begin{array}{l}\text { Circum } \\
\text { Arctic zones }\end{array}$ & SST & SSS & Sea Ice \\
\hline High-Arctic & $-2-0$ & $33-34$ & High Arctic & $\begin{array}{l}\text { same as Nordic } \\
\text { Seas }\end{array}$ & $30-33$ & $\begin{array}{l}\text { Mulit year } \\
\text { pack ice, no } \\
\text { open water }\end{array}$ & High-Arctic & $-2-0$ & $30-34$ & $\begin{array}{l}\text { Mulit year pack } \\
\text { ice, no open } \\
\text { water }\end{array}$ \\
\hline Mid-Arctic & $0-2$ & $34-35$ & Low Arctic & $\begin{array}{l}\text { same as Nordic } \\
\text { Seas }\end{array}$ & $<32$ & $\begin{array}{l}\text { Moving first } \\
\text { year ice }<6 \\
\text { month open } \\
\text { waters }\end{array}$ & Mid-Arctic & $0-2$ & $<32-35$ & $\begin{array}{l}\text { Moving first } \\
\text { year ice }<6 \\
\text { month open } \\
\text { waters }\end{array}$ \\
\hline Low-Arctic & $2-4$ & $34-35$ & $\begin{array}{l}\text { Mixed Low } \\
\text { Arctic and } \\
\text { Subarctic }\end{array}$ & $0-4$ & $30-34$ & $\begin{array}{l}\text { Moving sea ice } \\
3-7 \text { months } \\
\text { open in summer }\end{array}$ & Sub-Arctic & $2-4$ & $30-35$ & $\begin{array}{l}\text { Moving sea ice } \\
3-7 \text { months } \\
\text { open in summer }\end{array}$ \\
\hline $\mathrm{A} / \mathrm{B}$ transition & $4-6$ & $34-35$ & & & & $\begin{array}{l}0-3 \text { months } \\
\text { with sea ice }\end{array}$ & $\begin{array}{l}\mathrm{A} / \mathrm{B} \\
\text { transitional }\end{array}$ & $4-6$ & $32-35$ & $\begin{array}{l}0-3 \text { months } \\
\text { with sea ice }\end{array}$ \\
\hline High-Boreal & $6-8$ & $34-35$ & Subarctic & $2-6$ & $32-34,9$ & $\begin{array}{l}0-3 \text { months of } \\
\text { sea ice/small } \\
\text { floes }\end{array}$ & High-Boreal & $6-8$ & $32-35$ & $\begin{array}{l}0-3 \text { months of } \\
\text { sea ice/small } \\
\text { floes }\end{array}$ \\
\hline Mid-Boreal & $8-10$ & $34-35$ & $\begin{array}{l}\text { Subarctic and } \\
\text { Boreal }\end{array}$ & $6-10$ & $33.5-34.9$ & $\begin{array}{l}\text { Ice may form } \\
\text { in winter }\end{array}$ & Mid-Boreal & $8-10$ & $33-35$ & $\begin{array}{l}\text { Ice may form in } \\
\text { winter }\end{array}$ \\
\hline Low-Boreal & $10-16$ & $34-35$ & $\begin{array}{l}\text { Boreal warm } \\
\text { slope water and } \\
\text { Irminger Sea } \\
\text { Water }\end{array}$ & $8-16(20)$ & $34-35$ & & Sub-Boreal & $10-16$ & $634-35$ & No ice \\
\hline
\end{tabular}

in the model. Vegetation is incorporated with a landsurface transfer model (LSX; Pollard et al., 2000) with vegetation attributes determined by an interactive predictive vegetation model (EVE; Bergengren and Thompson, in review). Greenhouse gases were prescribed to approximate Holocene values (Appendix B of Pollard et al., 2000). For the $10 \mathrm{ka}$ simulation, land, ocean, and ice-sheet boundaries were from ICE-4G (Peltier, 1994), modified to allow communication between the Arctic Ocean and the North Pacific through Bering Strait (Fairbanks, 1989; Elias et al., 1996), and to include large proglacial lakes in North America and Fennoscandia. At $10 \mathrm{ka}$, obliquity was $0.8^{\circ}$ greater than present, perihelion was in July, and there was a slight increase in eccentricity, resulting in $40-50 \mathrm{~W} \mathrm{~m}^{-2}$ more insolation than present in June and July, and a corresponding decrease in autumn ( $\mathrm{S}, \mathrm{O})$ insolation. A substantial remnant of the Laurentide Ice Sheet remained over North-Central Canada, and a much smaller ice-sheet remnant remained over the higher elevations in Scandinavia. By $6 \mathrm{ka}$, except for the small Foxe Dome remnant of the Laurentide Ice Sheet, Pleistocene ice sheets had disappeared; surface topography in the model is the same as at present, and trace gases are prescribed as at $10 \mathrm{ka}$. Summer insolation in the Arctic was still $20-30 \mathrm{~W} \mathrm{~m}^{-2}$ above modern, whereas autumn insolation was only slightly lower than modern values.

\section{Data-model comparisons}

To compare the paleodata reconstructions and model simulations for 10 and $6 \mathrm{ka}$, the two datasets are superimposed in Figs. 4 and 5. These maps, and additional maps showing the site-specific CAPE Tundra Biomes derived from the pollen data for all 10 time slices, and predicted vegetation from the GENESIS 6 and $10 \mathrm{ka}$ simulations are available on the CAPE Website (http://www.ngdc. noaa.gov/paleo/cape/cape.html).

\subsection{Data-model comparison at $10 \mathrm{ka}$.}

The largest departures from present occurred at $10 \mathrm{ka}$, when orbital forcing was strongest, and the residual Laurentide and, to a lesser extent, Scandinavian ice sheets were still regionally influential. Unlike a glacial maximum simulation (Felzer et al., 2000), the remnant ice sheets at $10 \mathrm{ka}$ are sufficiently reduced in their aerial and vertical extent that they no longer exert a large circumpolar influence on the zonal wave pattern circulation of the 


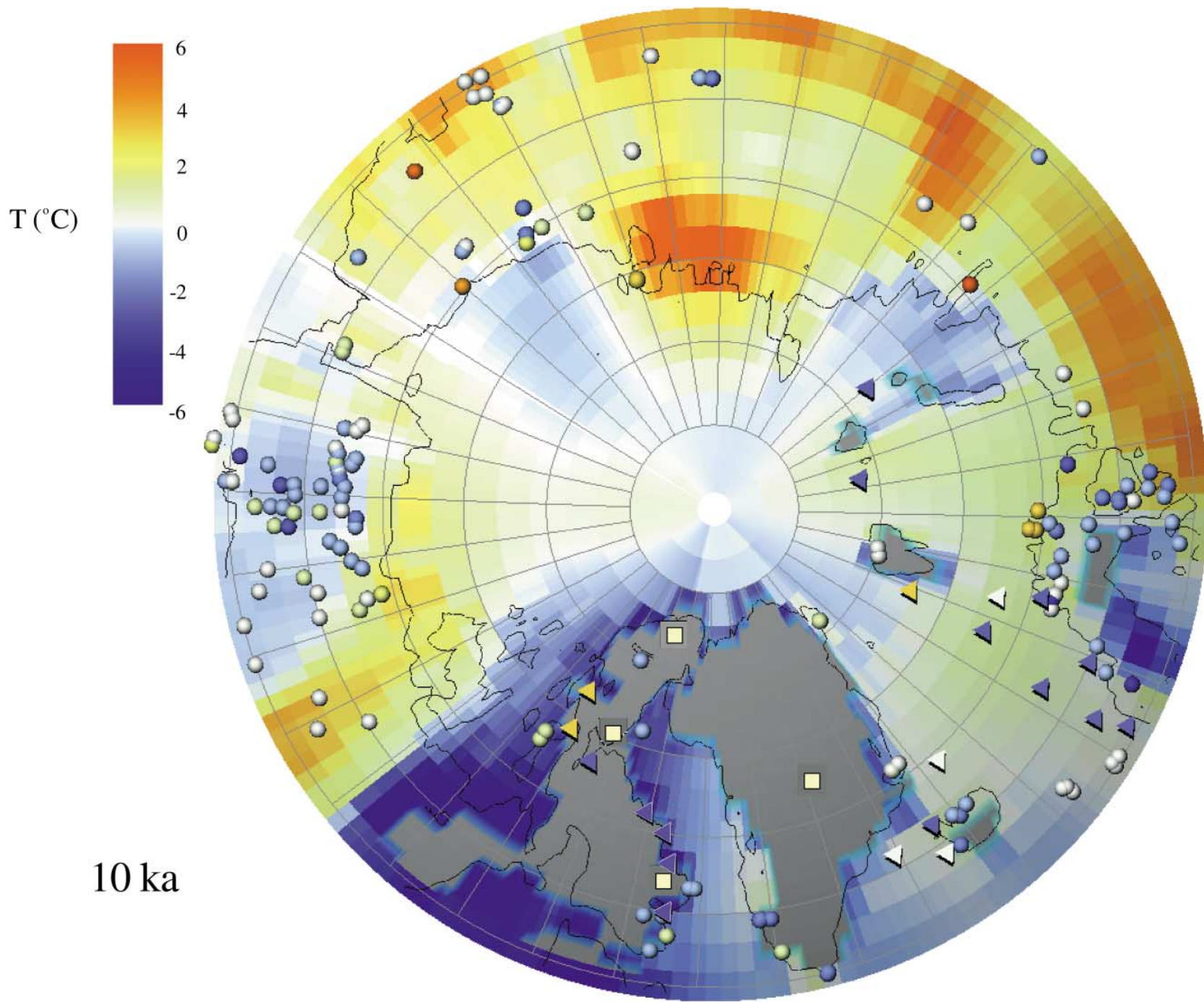

Fig. 4. Paleodata-model comparison for $10 \mathrm{ka}$. For both schemes, we show the departures of mean summer (JJA) temperatures from those of the present. In the model simulations, summer temperatures are scaled quantitatively as departures from the modern (control run using modern boundary conditions and pre-industrial $\mathrm{CO}_{2}$ ) monthly means. The paleovegetation data are scaled in a semi-quantitative scheme using color and intensity of color to indicate the direction and magnitude of change from present, based on a qualitative growing season temperature index derived from the CAPE Tundra Biomes (Fig. 1). Sea-surface temperatures are expressed as warmer (orange), colder (blue), or no different (white) than present based on a comparison of reconstructed water-mass type to present-day water mass at the site (Table 2). Ice-core data indicate whether the site in significantly warmer than (orange), colder than (blue), or the same as (white) present based on a comparison of $\delta^{18} \mathrm{O}$ values with surface samples. Select regions where glacier margins are behind current margins are indicated by orange diamonds. Gray areas are those regions covered by permanent ice sheets. Smoothed continental margins are from Peltier (1994) and are adjusted for sea-level changes. Note that on the 10 ka map there is a region of intensely warmer summers along the Russian Arctic coast east of Taimyr Peninsula. This warmth is because the region is considered land in the model at $10 \mathrm{ka}$, but was subsequently submerged due to sea-level rise and coastal erosion, and is ocean (sea-ice-covered) in the present-day control simulation. The apparent warmth at $10 \mathrm{ka}$ in this region of changed surface type is not of climatic significance.

middle troposphere. Thus, the resulting pattern of Arctic summer surface temperatures are determined primarily by a balance among the general increase in insolation, the slight cooling from pre-industrial greenhouse gas concentrations (a minor effect), circulation influences on a regional scale, and any resulting vegetation or sea-ice feedbacks.

The modeled $10 \mathrm{ka}$ summer temperature patterns are dominated, as expected, by strong cooling over and downstream of the remnant Laurentide Ice Sheet. Downstream cooling extends across a cooler simulated North Atlantic and into Western Europe and the southern Norwegian Sea. Marine and terrestrial proxies support the simulations across most of this region, but indicate that SSTs across the northern Norwegian Sea and air temperatures over adjacent arctic islands were similar to or warmer than present by $10 \mathrm{ka}$. The marine data in particular, require a stronger-than-present flow of 


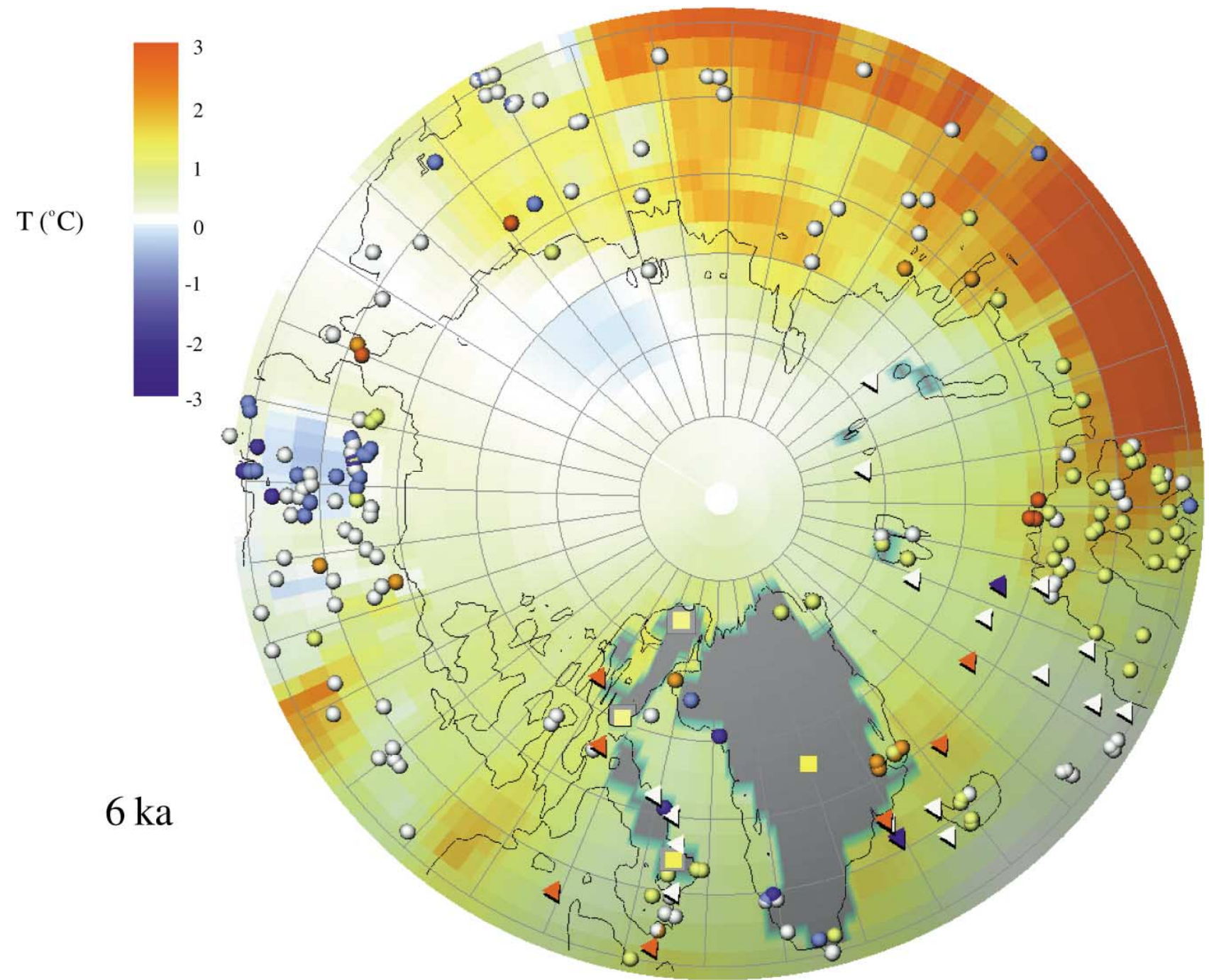

Fig. 5. Paleodata-model comparison for $6 \mathrm{ka}$. For both schemes, we show the departures of mean summer (JJA) temperatures from those of the present. In the model simulations, summer temperatures are scaled quantitatively as departures from the modern (control run using modern boundary conditions and pre-industrial $\mathrm{CO}_{2}$ ) monthly means. The paleovegetation data are scaled in a semi-quantitative scheme using color and intensity of color to indicate the direction and magnitude of change from present, based on a qualitative growing season temperature index derived from the CAPE Tundra Biomes (Fig. 1). Sea-surface temperatures are expressed as warmer (orange), colder (blue), or no different (white) than present based on a comparison of reconstructed water-mass type to present-day water mass at the site (Table 2). Ice-core data indicate whether the site in significantly warmer than (orange), colder than (blue), or the same as (white) present based on a comparison of $\delta^{18} \mathrm{O}$ values with surface samples. Select regions where glacier margins are behind current margins are indicated by orange diamonds. Gray areas are those regions covered by permanent ice sheets. Smoothed continental margins are from Peltier (1994) and are adjusted for sea-level changes. Note that on the 10 ka map there is a region of intensely warmer summers along the Russian Arctic coast east of Taimyr Peninsula. This warmth is because the region is considered land in the model at $10 \mathrm{ka}$, but was subsequently submerged due to sea-level rise and coastal erosion, and is ocean (sea-ice covered) in the present-day control simulation. The apparent warmth at $10 \mathrm{ka}$ in this region of changed surface type is not of climatic significance.

relatively warm Atlantic water into the Arctic Ocean via Fram Strait and along the north coast of Scandinavia. Because source water in the North Atlantic was cooler than present, SSTs in the southern Norwegian Sea remained lower than present despite intensification of the NAD. In contrast, the greater flux of Atlantic water at the current northern and eastern limits of the NAD, amplified by higher summer insolation, resulted in warmer than present conditions throughout these regions. This interpretation is supported by the appearance of marine mollusks with reproductive cycles limited by SST along the west and north coasts of Svalbard at $10 \mathrm{ka}$, well north of their current northern limits (Salvigsen et al., 1992), and observations that local glaciers were smaller than present by $10 \mathrm{ka}$ on both Svalbard (Svendsen and Mangerud, 1997) and Franz Josef Land (Lubinski et al., 1999). A similar increase in the penetration of warm Atlantic water along West Greenland and into the 
Canadian Arctic occurred about a thousand years later (Dyke, 1998; Funder and Weidick, 1991). GENESIS is not designed to predict changes in the intensity of meridional ocean currents (oceanic heat flux is prescribed, and the ocean is defined as a mixed slab ocean lacking deep convection), hence fails to capture this important effect.

Across the Eurasian Arctic to western Alaska the GCM simulates summers significantly warmer than present. This broad expanse of early Holocene relative warmth is a consequence of increased summer insolation. Paleodata indicate summer temperatures were similar to, rather warmer than present across most of this region, suggesting the model over-estimates the magnitude of the insolation effect across the interior of the Asian Arctic. The exception is along the Arctic Ocean coast where paleodata document a northward expansion of the boreal forest, suggesting warmer summers. However, at this time the coastline was several tens of kilometers north of its current position because sea level was lower and the continental shelf broad, with a very low slope. Coastal erosion accompanied the deglacial eustatic rise, producing a large southward shift of the coastline across this region during the early Holocene. At least some of the northward expansion of boreal forest at $10 \mathrm{ka}$ was due to the strong continentality caused by the distance to the Arctic Ocean at that time, and may not be directly related to differences in climate.

The paleodata indicate an abrupt shift from warmer to cooler summers eastward from western Alaska. This trend is captured well by the model, where it arises from a substantial increase in southwesterly surface flow. A stronger summer high-pressure area over the Gulf of Alaska at $10 \mathrm{ka}$ brought cool maritime air from the northern Pacific into the Alaskan interior. A similar effect occurs during the period of instrumental record, but the effect is simulated to have been much stronger at $10 \mathrm{ka}$. The increased maritime influence seen in both the $10 \mathrm{ka}$ data and model fades to the north and east over central Canada, where both reconstructions show minor changes or slight warming upstream of the residual Laurentide Ice Sheet.

Ice cores from high elevations on Greenland and Arctic Canada indicate summer melt was close to its maximum level at $10 \mathrm{ka}$, whereas terrestrial vegetation from lower elevations in the same regions indicates summer temperatures remained below their Holocene maxima. The summer melt at the summits of ice caps/ice sheets apparently responds more directly to summer insolation than does lower elevation vegetation, possibly because the higher insolation receipts were moderated at lower elevations by localized cooling from the residual Laurentide Ice Sheet.

\subsection{Data-model comparison at $6 \mathrm{ka}$.}

A consistent broad-scale pattern of warming to varying degrees is nearly circum-arctic in extent for both reconstructions at $6 \mathrm{ka}$. The proxy data indicates that terrestrial and marine temperatures are consistently higher than present across the Atlantic sector, but tend to be similar to the present elsewhere. The only regional exception to this pattern is Alaska, which is generally cooler than present in both the observations and the GCM simulation. As at $10 \mathrm{ka}$, the GCM output suggests this is due to a stronger flow of cool air from the Pacific than at present, but the strength of this flow is less than at $10 \mathrm{ka}$. Summer warmth at $6 \mathrm{ka}$ in the Atlantic sector may be particularly apparent because it is over this region that Neoglaciation, the re-growth of glaciers in the Midto Late-Holocene (and associated reduction of summer temperatures), is best demonstrated. This spatially coherent pattern of Late Holocene cooling may be related to changes in the routing of Atlantic water into the Arctic (Hald and Aspeli, 1997), and/or the rate of deepwater formation in the Nordic and Labrador seas, which strongly influences the poleward transport of heat by the ocean (e.g., Carissmo et al., 1985).

The greatest discrepancy between paleodata and model simulations occurs across the Eurasian Arctic, where the GCM predicts summer temperatures $3^{\circ} \mathrm{C}$ above present and an extensive expansion of grasslands at the expense of boreal forest (Pollard et al., 2000). In contrast, pollen records indicate vegetation similar to modern throughout the region at that time. Similar results have been noted for other $6 \mathrm{ka}$ simulations (Prentice et al., 1998), although a GCM experiment utilizing a non-interactive vegetation model did not predict the grassland expansion (TEMPO, 1996). The discrepancy may be due to a vegetation-climate feedback (Bonan et al., 1995) arising from an inaccurate specification of summer temperature limits for deciduous broadleaf trees (e.g., birch) in the EVE model, or it may infer the limits of climate models that lack a fully coupled ocean.

\section{Conclusions}

The comparison of terrestrial, ice core, and marine paleodata with GCM simulations, undertaken here for the first time for the Arctic, shows broad agreement despite the asymmetric response of the Arctic to symmetrical forcing (insolation, $\mathrm{CO}_{2}$ ). Asymmetry is enhanced by the relatively slow decay of the Laurentide Ice Sheet relative to the Eurasian ice sheets, and by changes in thermohaline circulation and associated changes in the intensity of the NAD compared to less dramatic changes in surface and deep circulation in the North Pacific. Late Holocene cooling, well expressed in the paleodata throughout the North Atlantic sector, is not mirrored in Beringia, and is likely a consequence of subtle changes in North Atlantic circulation.

The GCM simulation performs well overall, capturing early Holocene warming across the Eurasian Arctic and 
the lack of Late Holocene cooling over Alaska, but greatly overpredicts Mid-Holocene summer temperatures across Russia, apparently a consequence of inappropriate temperature limits in the associated vegetation model.

Although changes in Laurentide and Fennoscandinavian ice sheets and insolation account for many of the dominant features apparent in Figs. 4 and 5, interactions within the global climate system complicate specific predictions of environmental change. GENESIS is not designed to capture changes in ocean currents; consequently the failure of the GCM to capture early Holocene intensification of the NAD is not surprising. This discrepancy does suggest that algorithms for meridional heat transport by ocean currents and thermohaline convection will have to be incorporated in future models to accurately assess past and future environmental change.

Continued comparisons between climate models and well-constrained paleo-datasets offer the potential of identifying flaws in the models and weaknesses in the paleodata, and will focus paleo-research in critical geographic regions and at key time slices. One obvious gap in the paleodata for the Arctic is the absence of welldated proxy records of sea-ice changes (cf, Koç et al., 1993) in the Arctic Ocean and some of the associated marginal seas. Sea ice is a key variable in assessing climate change because of its large feedback on the planetary energy balance and deep-ocean convection. The extent and duration of sea-ice cover influence the planetary albedo and the exchanges of heat, moisture, and gases between ocean and atmosphere. Sea-ice formation alters the salinity structure of surface waters through salt rejection, producing cold, dense brines. A reduction of permanent sea ice under a $2 \times \mathrm{CO}_{2}$ scenario is largely responsible for the modeled intense warming of the Arctic in the next century. A rigorous reconstruction of the extent of sea-ice reduction in the early Holocene, when increased advection of warm Atlantic water coincided with a maximum in summer insolation, provides the most recent "warm Earth" analogue for projected future warming. Accurate paleoreconstructions of sea ice allow evaluation of the next generation of sea-ice models, underscoring the continuing need to bring together the paleo-data and modeling communities to compare observed changes in the past with modeled paleo-simulations. These interactions provide the most effective validation of models being used to make essential projections of future climates.

\section{Acknowledgements}

The compilation of paleodata reported here was made possible only by the collaborative input from a wide range of international specialists. Initial meetings of each of the 12 regional working groups were held to identify well-dated proxy records, and to convert the pollen data to biomes for the Lammi meeting. The CAPE-Holocene meeting was held from 5 to 7 April 1997 in Lammi, Finland. During this meeting, refinement of the classification process was undertaken to develop a better consensus classification system, and initial pollen compilations were revised to reflect the new classification. A series of subsequent smaller workshops were held in Europe and North America to develop the rule-based classification system for marine proxies, and to refine regional aspects of the terrestrial summer temperature reconstructions.

We thank all of the experts who assisted the 13 regional working groups in developing the regional compilations, and the contributors who attended the Lammi meeting. We thank Paul Morin of the University of Minnesota for assistance with the superposition of GCM output and paleodata.

The CAPE Lammi meeting was supported by the PAGES Core Office, the Academy of Finland, the Norwegian Science Foundation, and the U.S. National Science Foundation's Earth System History Program Office.

\section{Appendix A. CAPE Steering Committee}

Ole Bennike

Dmitry Bolshiyanov ${ }^{3}$

Julian Dowdeswell

Anders Elverhøi ${ }^{3}$

Áslaug Geirsdóttir ${ }^{3}$

Sheila Hicks

Hans Hubberton

Olafur Ingólfsson

Gifford Miller ${ }^{3}$
GEUS, Thoraej 8, DK-2400 Copenhagen, Denmark

Polar Geography, AARI, 38 Bering St., 199226 St. Petersburg, Russia

Bristol Glaciology Centre, University of Bristol, Bristol BS8 ISS, U.K.

Institute of Geology, Univ. Oslo, Box 1047, Blindern, Oslo 3, Norway

Department of Geosciences, University of Iceland, 101 Reykjavik, Iceland

Department of Geosciences, University of Oulu, Oulu 10, SF-90100, Finland

AWI, Telegraphenberg A43, Postdam 1561, Germany

UNIS, Longyearbyen, Svalbard, Norway

INSTAAR, University of Colorado, Boulder, CO 803090450, USA

\footnotetext{
${ }^{3}$ Indicates Executive Committee members.
} 


\begin{tabular}{|c|c|}
\hline $\begin{array}{l}\text { Peta Mudie/Steve } \\
\text { Solomon }\end{array}$ & $\begin{array}{l}\text { BIO, Atlantic Geoscience } \\
\text { Center, Dartmouth, NS, B2Y } \\
\text { 4A2 Canada }\end{array}$ \\
\hline Starley Thompson & $\begin{array}{l}\text { NCAR, PO Box } 3000 \text {, Boulder, } \\
\text { CO } 80307 \text { USA }\end{array}$ \\
\hline Rein Vaikmae & $\begin{array}{l}\text { Inst. of Geology, Tallinn Tech } \\
\text { nical University, } 10143 \text { Tallin } \\
\text { Estonia }\end{array}$ \\
\hline Tore Vorren & $\begin{array}{l}\text { Depts. Geology and Biolo } \\
\text { University of Troms } \varnothing \text {, Trom } \\
\text { 9001, Norway }\end{array}$ \\
\hline
\end{tabular}

\section{Appendix B. CAPE Holocene Meeting Participants, Lammi, Finland}

Anderson, Pat, pata@u.washington.edu Quaternary Research Centre, University of Washington, USA

Andreev, Andrei, aandreev@AWI-Potsdam.DE Alfred Wegener Institute for Polar and Marine Research, Germany

Andrews, John, andrewsj@spot.colorado.edv

INSTAAR, University of Colorado, USA

Bennike, Ole, obe@geus.dk

GEUS, Denmark

Blasco, Steve, blasco@agc.bio.ns.ca

Geological Survey of Canada, Bedford Institute Oceanography, Canada

Bolshyanov, Dmitry, bolshiyanov@aari.nw.ru

Polar Geography Department, Arctic and Antarctic

Research Institute, Russia

Brubaker, Linda,1bru@u.washington.edu

College of Forest Resources, University of Washington, Seattle, USA

Buckland, Paul, p.buckland@sheffield.ac.uk

Department of Archaeology and Prehistory, University of Sheffield, UK

Dyke, Art, ad@gsc.nrcan.gc.ca

Geological Survey of Canada, Ottawa, Canada

Edwards, Mary, Mary.Edwards@sv.ntnu.no

Institute of Geography, University of Trondheim, Norway

Elina, Galina, elina@post.kre.karelina.ru

Institute of Biology, Karelian Research Centre, Russia

Elverhøi, Anders, anders.elverhøi@geologi.uio.no

Institute of Geology, University of Oslo, Norway

Felzer, Benjamin, felzer@ogp.noaa.gov

NOAA, Office of Global Programs, USA

Filiminova, Ludmila, filimonova@post.kre.karelia.ru

Institute of Biology, Karelian Research Centre, Russia

Geirsdóttir, Áslaug, age@rhi.hi.is

Geosciences, University of Iceland, Iceland

Hald, Morten, mortenh@ibg.uit.no

Department of Geology, University of Troms $\varnothing$, Norway
Hardardóttir, Jorunn, jha@os.is

Jardfraedahus Haskolans, University of Iceland, Iceland

Hicks, Sheila, sheila.hicks@oulu.fi

Institute of Geosciences, University of Oulu, Finland

Hubberten, Hans, hubbert@awi-potsdam.de

Alfred Wegener Institute for Polar and Marine Research, Germany

Hyvärinen, Hannu, hannu.hyvarinen@helsinki.fi

Department of Geology, University of Helsinki, Finland

Ikonen, Liisa, liisa.ikonen@gsf.fi

Geological Research Centre, Espoo, Finland

Kassens, Heidimarie, hkassens@geomar.de

Forschungszentrum GEOMAR, Kiel, Germany

Khomutova, Valentina, postmast@lake.spb.su

Institute of Limnology, Russian Academy of Sciences, St. Petersburg, Russia

Lozhkin, Anatoly, strujkov@trumpe.neisri.magadan.su North East Interdisciplinary Science Research Institute, Russian Academy of Sciences, Magadan, Russia

MacDonald, Glen, macdonal@geog.ucla.edu

Department of Geography, UCLA, USA

Makeev, Vyacheslav, makeev@aari.nw.ru

Polar Geography Department, Arctic and Antarctic

Research Institute, St. Petersburg, Russia

Miller, Gifford, gmiller@colorado.edu

INSTAAR, University of Colorado, Boulder, USA

Mudie, Peta,mudie@agc.bio.ns.ca

Geological Survey of Canada, Dartmouth, Nova Scotia, Canada

Savelieva, Larisa, savelieval@mail.ru

Institute of Geography, St. Petersburg University, Russia

Seppä, Heikki, heikki.seppa@geo.uu.se

Department of Quaternary Geology, Uppsala University, Sweden

Spear, Ray, spear@uno.cc.geneseo.edu

Department of Biology, State University of New York at Geneseo, USA

Zielinski, Gregory, gzielinski@marine.edu

Institute for Quaternary and Climate Studies, University of Maine, USA

\section{References}

Bartlein, P.J., Anderson, K.H., et al., 1998. Paleoclimate simulations for North America over the past 21,000 years: features of the simulated climate and comparisons with paleoenvironmental data. Quaternary Science Reviews 17, 549-585.

Bergengren, J.C., Thompson, S.L. in review. Modeling the effects of global climate change on natural vegetation, Part 1: the Equilibrium Vegetation Ecology model. Global Planetary Change.

Bonan, G.B., Chapin, F.S.I., Thompson, S.L., 1995. Boreal forest and tundra ecosystems as components of the climate system. Climatic Change 29, 145-167.

Carissmo, B.C., Oort, A.H., Vonder Haar, T.H., 1985. Estimating the meridional energy transports in the atmosphere and oceans. Journal of Physical Oceanography 15, 82-91. 
COHMAP Project Members, 1988. Climate changes of the last 18,000 years: observations and model simulations. Science 241, $1043-1052$.

Dyke, A.S. Dale, J.E., McNeely, R.N., 1996. Morine Mollusces as indicators of environmental change in glaciated North America and Greenland during the last 18,000 years. Géographie physique et Quarternaire, 36, 5-14.

Elias, S.A., Short, S.K., Nelson, C.H., Birks, H.H., 1996. Life and times of the Bering land bridge. Nature 382, 60-63.

Fairbanks, R.G., 1989. A 17,000 year glacio-eustatic sea level record: influence of glacial melting rates on the Younger Dryas event and deep-ocean circulation. Nature 342, 637-642.

Felzer, B.S., Thompson, S.L., Pollard, D., Bergengren, J.C., 2000. GCM-simulated hydrology in the Arctic during the past 21,000 years. Journal of Paleolimnology, 24, 15-28.

Feyling-Hanssen, R.W., Jørgensen, J.A., Knudsen, K.-L., Andersen, A.-L.L., 1971. Late quaternary foraminifera from Vendsyssel, Denmark and Sandnes, Norway. Bulletin of the Geological Society of Denmark 21, 61-317.

Foley, J.A., Kutzbach, J.E., Coe, M.T., Levis, S., 1994. Climate and vegetation feedbacks during the mid-Holocene. Nature 371, $52-54$.

Foley, J.A., Prentice, I.C., Romankutty, N., Levis, S., Pollard, D., Sitch, S., Haxeltine, A., 1996. An integrated biosphere model of land surface processes, terrestrial carbon balance, and vegetation dynamics. Global Biogeochemical Cycles 10, 603-628.

Funder, S., Weidick, A., 1991. Holocene boreal molluscs in Greenland: paleoceanographic implications. Palaeogeography, Palaeoclimatology, Palaeoecology 85, 123-135.

Hald, M., Aspeli, R., 1997. Rapid climatic shifts of the northern Norwegian Sea during the last deglaciation and the Holocene. Boreas 26, $15-28$.

Hastenrath, S., 1982. On meridional heat transports in the World Ocean. Journal of Physical Oceanography 12, 922-927.

Hicks, S., 1997. Holocene Spatial and Temporal Patterns of Environmental Change in the Arctic. Abstracts Volume, Lammi, Finland, April, 1997.

Jennings, A.E., Weiner, N.W., 1996. Environmental change in eastern Greenland during the last 1300 years: evidence from foraminifera and lithofacies in Nansen Fjord, $68^{\circ} \mathrm{N}$. The Holocene 6, 179-191.

Jolly, D., Harrison, S.P., et al., 1998. Simulated climate and biomes of Africa during the Late Quaternary: comparison with pollen and lake status data. Quaternary Science Reviews 17, 629-657.

Joussaume, S., Taylor, K., 1998. In: F. Oldfield (Ed.), Climate modeldata comparisons, Palaeoclimate Modelling Intercomparison Project (PMIP). IGBP Report 45: PAGES Status Report and Implementation Plan. Stockholm, 173-178.

Koç, N.E., Jansen, E., Haflidason, H., 1993. Paleoceanographic reconstruction of surface ocean conditions in the Greenland, Iceland, and Norwegian seas through the last 14,000 years based on diatoms. Quaternary Science Reviews 12, 115-140.

Koerner, R.M., 1977. Devon Island ice cap: core stratigraphy and paleoclimate. Science 196, 15-18.

Kohfeld, K.E., Harrison, S.P., 2000. How well can we simulate past climates? Evaluating the models using global paleoenvironmental datasets. Quaternary Science Reviews 19, 321-346.

Kutzbach, J.E., Bonan, G., Foley, J., Harrison, S.P., 1996. Vegetation and soil feedbacks on the response of the African monsoon to orbital forcing in the early to middle Holocene. Nature 384, 623-626

Lubinski, D.J., Forman, S.L., Miller, G.H., 1999. Holocene glacier and climate fluctuations on Franz Josef Land, Arctic Russia, $80^{\circ} \mathrm{N}$. Quaternary Science Reviews 18, 85-108.

Mitchell, J.F.B., Johns, T.C., Gregory, J.M., Tett, S.F.B., 1995. Climate response to increasing levels of greenhouse gases and sulphate aerosols. Nature 376, 501-504.
Mudie, P.J., Keen, C.E., Hardy, I.A., Vilks, G., 1984. Multivariate analysis and quantitative paleoecology of benthic foraminifera in surface and late quaternary shelf sediments, northern Canada. Marine Micropaleontology 8, 283-313.

Oldfield, F., 1998. PAGES Status Report and Implementation Plan. IGBP Report 45.

Overpeck, J., Hughen, K., Hardy, D., Bradley, R., Case, R., Douglas, M., Finney, B., Gajewski, K., Jacoby, G., Jennings, A., Lamoureux, S., Lasca, A., MaDonald, G., Moore, J., Retelle, M., Smith, S., Wolfe, A., Zielinski, G., 1997. Arctic environmental change of the last four centuries. Science 278, 1251-1256.

Peltier, W.R., 1994. Ice age paleotopography. Science 265, 195-201.

Pflaumann, U., Duprat, J., Pujol, C., Labeyrie, L.D., 1996. SIMMAX: A modern analog technique to deduce Atlantic sea surface temperatures from planktonic foraminifera in deep-sea sediments. Paleoceanography 11, 15-35.

Pollard, D., Bergengren, J.C., Stillwell-Soller, L.M., Felzer, B.S., Thompson, S.L., 2000. Climate simulations for 10,000 and 6000 years BP using the GENESIS Global Climate Model. Paleoclimates, Data and Modelling, 2, 183-218.

Prentice, I.C., Cramer, W., Harrison, S.P., Leemans, R., Monserud, Soloman, A.M., 1992. A global biome model based on plant physiology and dominance, soil properties and climate. Journal of Biogeography 19, 117-134.

Prentice, I.C., Guiot, J., Huntley, B., Jolly, D., Cheddadi, R., 1996. Reconstructing biomes from palaeoecological data: a general method and its application to European pollen data at 0 and $6 \mathrm{ka}$. Climate Dynamics 12, 185-194.

Prentice, I.C., Harrison, S.P., Jolly, D., Guiot, J., 1998. The climate and biomes of Europe at $6000 \mathrm{yr}$ BP: comparison of model simulations and pollen-based reconstructions. Quaternary Science Reviews 17, 659-668.

Prentice, I.C., Webb III, T., 1998. BIOME 6000: reconstructing global mid-Holocene vegetation-patterns from paleoecological records. Journal of Biogeography 25, 997-1005.

Salvigsen, O., Forman, S.L., Miller, G.H., 1992. Thermophilous molluscs on Svalbard during the Holocene and their paleoclimatic implications. Polar Research 11, 1-10.

Sejrup, H.-P., Fjæran, T., Hald, M., Beck, L., Hagen, J., Miljeteig, I., Morvik, I., Norvik, O., 1981. Benthonic foraminfera in surface samples from the Norwegian continental margin between $62^{\circ} \mathrm{N}$ and $65^{\circ} \mathrm{N}$. Journal of Foraminiferal Research 11, 277-295.

Stein, R., 1998. Arctic Paleo-River Discharge (APARD), pp. 129. Berichte zur Polarforschung.

Svendsen, J.I., Mangerud, J., 1997. Holocene glacial and climactic variations on Spitsbergen, Svalbard. The Holocene 7, 45-67.

TEMPO, 1996. Potential role of vegetation feedbacks in the climate sensitivity of high-latitude regions: a case study at 6000 years B.P. Global Biogeochemical Cycles 10, 727-736.

Thompson, S.L., Pollard, D., 1997. Greenland and Antarctic mass balances for present and doubled atmospheric $\mathrm{CO}_{2}$ from the GENESIS version 2 global climate model. Journal of Climate 10, 871-900.

de Vernal, A., Turon, J.-L., Guiot, J., 1994. Dinoflagellate cyst distribution in high latitude environments and quantitative reconstruction of sea-surface temperature, salinity and seasonality. Canadian Journal of Earth Sciences 31, 48-62.

de Vernal, A., Rochon, A., Turon, J.-L., Matthiessen, J., 1997. Organicwalled dinoflagellate cysts: palynological tracers of sea-surface conditions in middle to high latitude marine environments. GEOBIOS 30, 905-920.

Waelbroeck, C., Labeyrie, L., Duplessy, J.-C., Guiot, J., Labracherie, M., Leclaire, H., Duprat, J., 1998. Improving past sea-surface temperature estimates based on planktonic fossil faunas. Paleoceanography $13,272-283$.

Webb, T. III. (Ed.), 1998. Late Quaternary climates: data synthesis and model experiments. Quaternary Science Reviews 17, 465-688. 
Webb III, T., Bartlein, P.J., et al., 1987. Climatic change in eastern North America during the past years; comparisons of pollen data with model results. In: Ruddiman, W.F., Wright, H.E. (Eds.), North America and adjacent oceans during the Last Deglaciation. Geological Society of America K-3, Boulder, CO, pp. 447-462.
Williams, J.W., Summers, R.L., Webb, T.I., 1998. Applying plant functional types to construct biome maps from Eastern North America pollen data: comparisons with model results. Quaternary Science Reviews 17, 607-627. 